\title{
Changes in Supercooling in Growing Leaves of Some Ever- green Plants and their Relation to Intercellular Space, Osmotic Value and Water Content
}

\author{
by Shosuke KAKU*
}

\section{Received December 2, 1965}

The cold-hardiness of plants in temperate climates increases during autumn, attains the maximum during mid-winter and decreases in spring. Also, cold-hardiness usually increases with maturity. Osmotic values and freezing points of plant tissues are closely associated with their cold-hardiness ${ }^{1,2}$. On the other hand, freezing may be avoided by supercooling below the freezing point. In general, solutes depress supercooling points to the same extent they depress freezing points ${ }^{3)}$, and sometimes more ${ }^{4)}$. Water loss or dehydration concentrates solutes and thereby lowers freezing points. Thus, it may be assumed that some increases in supercooling ability in plant tissues will be associated with the rise in osmotic value and the depression of the freezing point. However, there has been little work done on the changes of supercooling points of growing leaf tissues and its seasonal changes in winter. Supercooling points of univoltine insects exhibit periodicity, being high in summer, dropping in autumn, reaching a minimum during winter, and rising again in spring.

Morphological factors associated with plant cold-hardiness have been investigated by earlier workers; cell size especially has attracted attention ${ }^{2)}$. Molisch ${ }^{5)}$ and D'Arsonval $^{6)}$ suggested that small cell size might protect a plant from freezing by favoring supercooling, and Voigtländer ${ }^{7)}$ found that supercooling ability increased as the cross-section of intercellular spaces decreased.

In a previous paper ${ }^{8}$, the author stated that the epidermal cells of mature leaves in both Aspidistra and Viburnum were more frost hardy than those of immature leaves. The supercooling points of mature leaves of Aspidistra were lower than those of the immature ones, whereas in Viburnum the reverse was true. Further investigation is therefore required.

In the present paper, the changes in supercooling associated with leaf maturity and seasonal changes during the winter are investigated in relation to osmotic value, water content and the volume of intercellular space.

\section{Materials and Methods}

The leaf tissues of Aspidistra elatior, Viburnum odoratissimum and Fatsia japonica grown at our university campus were used. From the autumn of 1963 to the spring of 1964 the seasonal changes of supercooling points, osmotic values and water contents were measured in mature leaf tissues of these three plants. The changes of these characteristics accompanying the maturity of leaf tissues were periodically observed in immature leaves unfolded in the spring of 1964. At the same time, the relation between supercooling and volume of intercellular space was investigated with both

* Biological Laboratory, General Education Department, Kyushu University, Otsubo-machi, Fukuoka, Japan. 
immature and mature leaf tissues. The supercooling points, water contents and osmotic values were determined by methods previously described ${ }^{8)}$. The determination of seasonal changes of these characteristics were carried out monthly on ten leaf pieces obtained from ten different leaves. In the measurement of supercooling points of leaf pieces, the cooling rates employed were about $2 \sim 3^{\circ}$ per minute at $0^{\circ}$, decreasing from this value as the temperature fell.

The volumes of intercellular space were measured with the buoyancy method devised by Katayama and Imamura ${ }^{9},{ }^{10,11}$. The leaf pieces were weighed to the nearest $0.5 \mathrm{mg}$ three times on a torsion balance: 1 . in air $\left(G_{1}\right) ; 2$. submerged in water $\left(G_{2}\right)$; 3. again submerged in water after being infiltrated with water under vacuum $\left(G_{3}\right)$. The volume of intercellular space is computed from $G_{3}-G_{2}$, and is converted to percentage of the volume of material $\left(G_{1}-G_{2}\right)$. In the present work, the replacement of air by water was completely achieved in 30 minutes in Viburnum, and in 15 minutes in Aspidistra at a pressure of about $8 \sim 10 \mathrm{mmHg}$. When determining supercooling points of material infiltrated with water, the surfaces were carefully blotted with filter paper, taking care not to lose any of the infiltrated water.

\section{Results and Discussion}

1. Relation between the changes of supercooling point and the changes of osmotic value and water content in overwintering maiure leaves and accompanying the maiuration of leaves

(a) Changes during overwintering

Changes in supercooling points, osmotic values and water contents during the winter and spring are shown on the left side of Figs. 1 and 2. The changes in supercooling points were limited to about $1^{\circ}$ in each species (Fig. 1). Throughout the season the order of supercooling ability was: Aspidistra $>$ Fatsia $>$ Viburnum.

The osmotic values of mature leaves increased toward winter, attaining maxima in January or February and decreased toward spring (Fig. 2). These seasonal changes of osmotic value are similar to those reported by many investigators ${ }^{2)}$. Their order was: Aspidistra $>$ Viburnum $>$ Fatsia. From an ecological point of view, it is interesting that the osmotic value of Aspidistra, which is herbaceous and a shade plant, is the highest of the three species, although herbaceous plants usually have a lower osmotic value than those of trees and shrubs ${ }^{12}$, and leaves grown in the shade have a lower osmotic value than those in the $\operatorname{sun}^{13)}$.

The water contents of mature leaves in Viburnum and Fatsia remained almost constant from November to May, while those of Aspidistra showed a progressive decrease (Fig. 2).

As mentioned above, the supercooling point and water content in the overwintering mature leaves did not show seasonal changes, and the typical change of osmotic value was observed in each plant. Osmotic values were converted into equivalent freezing point depressions (Fig. 1) in order to show how little they could affect supercooling points: about $0.2 \sim 0.4^{\circ}$ during autumn to midwinter.

\section{(b) Changes accompanying maturation}

The changes in supercooling point during maturation of the leaf tissues are shown on the right side of Fig. 1. The supercooling points of mature leaves in Aspidistra showed a pronounced decrease from June (about $-11^{\circ}$ ) to August (about $-13.5^{\circ}$ ) as the leaves grew. Mature leaves in May supercooled $2.8^{\circ}$ more than immature ones 
in June of the same year. On the other hand, in Viburnum and Fatsia there was no marked change in the supercooling points. However, in these two species the supercooling points of mature leaves in May are higher than those of immature ones in May by about $1.3^{\circ}$ in Viburnum and $1.0^{\circ}$ in Fatsia. Such a relation between the mature and immature leaves in Aspidistra and Viburnum is in good agreement with the data of the previous paper ${ }^{8}$. It may be concluded, therefore, that changes in supercooling accompany the maturity of leaf tissues, although the tendency is different among different species.

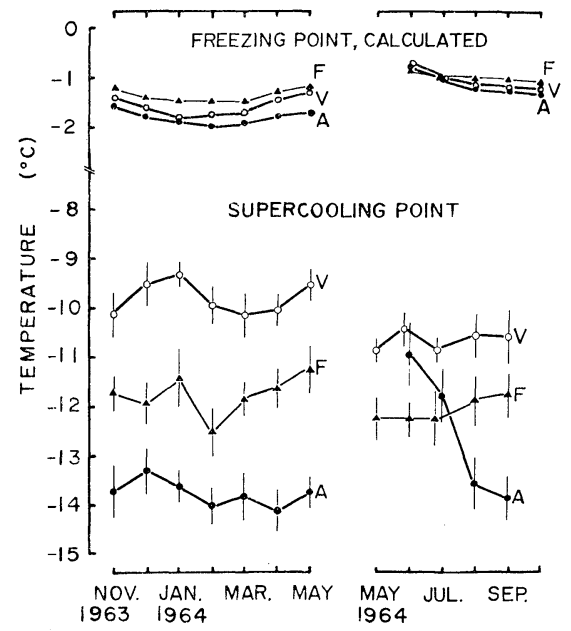

Fig. 1. Mean changes in supercooling and freezing points during winter and spring (left) and accompanying maturation (right) in leaf tissues of Aspidistra (A), Viburnum (V) and Fatsia (F). Freezing points were calculated from the osmotic values indicated in Fig. 2. Vertical bars represent the standard deviation.
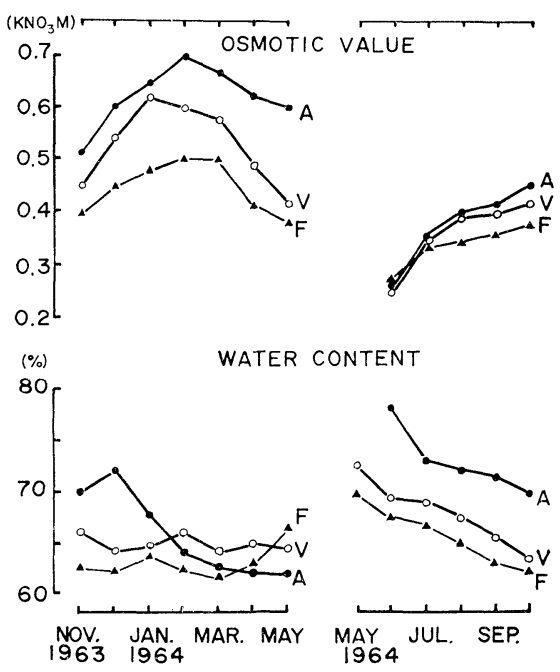

Fig. 2. Mean changes in osmotic value and water content during winter and spring (left) and accompanying maturation (right) in leaf tissues of Aspidistra (A), Viburnum (V) and Fatsia (F).

The osmotic values in the immature leaves of these three plants showed the same initial values, which gradually increased and differentiated with the aging of leaf tissues (Fig. 2). The water contents were larger in immature leaves, and decreased gradually as the leaves grew (Fig. 2). Increase of osmotic value and decrease of water content during maturation of plant tissues are well known ${ }^{14)}$.

In summary, the osmotic value gradually increased and water content decreased with the maturation of leaf tissues in each species, and the supercooling points fell only in Aspidistra, while the other two species showed no change. According to Salt ${ }^{15)}$, water loss or dehydration lowers supercooling points to the extent that it concentrates and thereby lowers freezing points, but he emphasizes that the change is very slight until dehydration becomes severe. Thus supercooling points in insects remain approximately constant over a wide range of moisture conditions. Although the difference of materials and size between insects and leaves must be considered, the water loss of leaf tissues in the present work was limited to about $5 \sim 7 \%$ and 
the freezing point depression about $0.4 \sim 0.5^{\circ}$ during maturation. It may be concluded that no change of supercooling point can be detected in immature leaves of either Viburnum or Fatsia as a result of these degrees of change in the water content and osmotic value, and that lowering of supercooling points in Aspidistra was not necessarily caused by only the two factors mentioned above.

\section{Relation between the changes of supercooling point and the changes of intercellular space accompanying the maturation of leaf tissues in Aspidistra and Viburnum}

As already mentioned, differences in supercooling points in both mature and immature leaf tissues of Aspidistra and Viburnum cannot be attributed to factors such as osmotic value and water content alone. Next, the changes in the volume of intercellular space associated with the maturity of leaves were examined, to determine if there were any relation between the volume of intercellular space and supercooling ability.

The volumes of intercellular space and the supercooling points of both mature and immature leaf tissues are shown in Table 1. In early summer, the mature leaves of Aspidistra showed larger volumes of intercellular space and lower supercooling points than the immature ones. When immature leaves matured by autumn, the intercellular space was increased and the supercooling points lowered almost to the same degree as in mature leaves of the early summer.

In Viburnum, on the other hand, the mature leaves had less intercellular space and higher supercooling points than the immature ones. The immature leaves in spring (May) were matured in autumn (September), when new immature leaves were again unfolded. At this time the differences of both intercellular space and supercooling points between the newly mature and immature leaves were more pronounced than in spring, i.e., the immature leaves appearing in autumn showed more intercellular space and lower supercooling points than the immature ones in spring.

According to Takenouchi ${ }^{16)}$, the young leaves of Photinica glabra showed larger intercellular spaces than the old ones by $2.59 \%$, although his measuring method differed from the present one. This is very similar to the data for Viburnum in May. It seems likely that the volume of intercellular space and supercooling point of the leaf tissue change as the tissue grows. Changes in intercellular space and supercooling points accompanying the aging of leaf tissues were quite different between Aspidistra and Viburnum. In Aspidistra the intercellular space increased and the supercooling points fell with the aging of tissues, while in Viburnum the former decreased and the latter rose. From these results, it is conceivable that supercooling ability in Aspidistra and Viburnum is related to change in volume of intercellular space.

This does not agree with Voigtländer's ${ }^{7)}$ results, however, which were obtained on different species and tissues and with different methods. Lucus ${ }^{17)}$ stated that Voigtländer's finding might be explained by the assumption that freezing nuclei (motes) in the atmosphere penetrated more quickly and deeply into tissues with larger intercellular spaces. Lucus found that detached lemon fruits nucleated between $-3.9 \sim-4.4^{\circ}$. However, it is not likely that motes from the atmosphere will cause spontaneous freezing in plant tissue at such high temperatures.

\section{Effect of water infiltration into intercellular space on the supercooling of leaves}

According to Iljin ${ }^{18)}$, plant tissues begin to freeze more easily when water has penetrated into their intercellular spaces. In the present work, changes in supercooling 


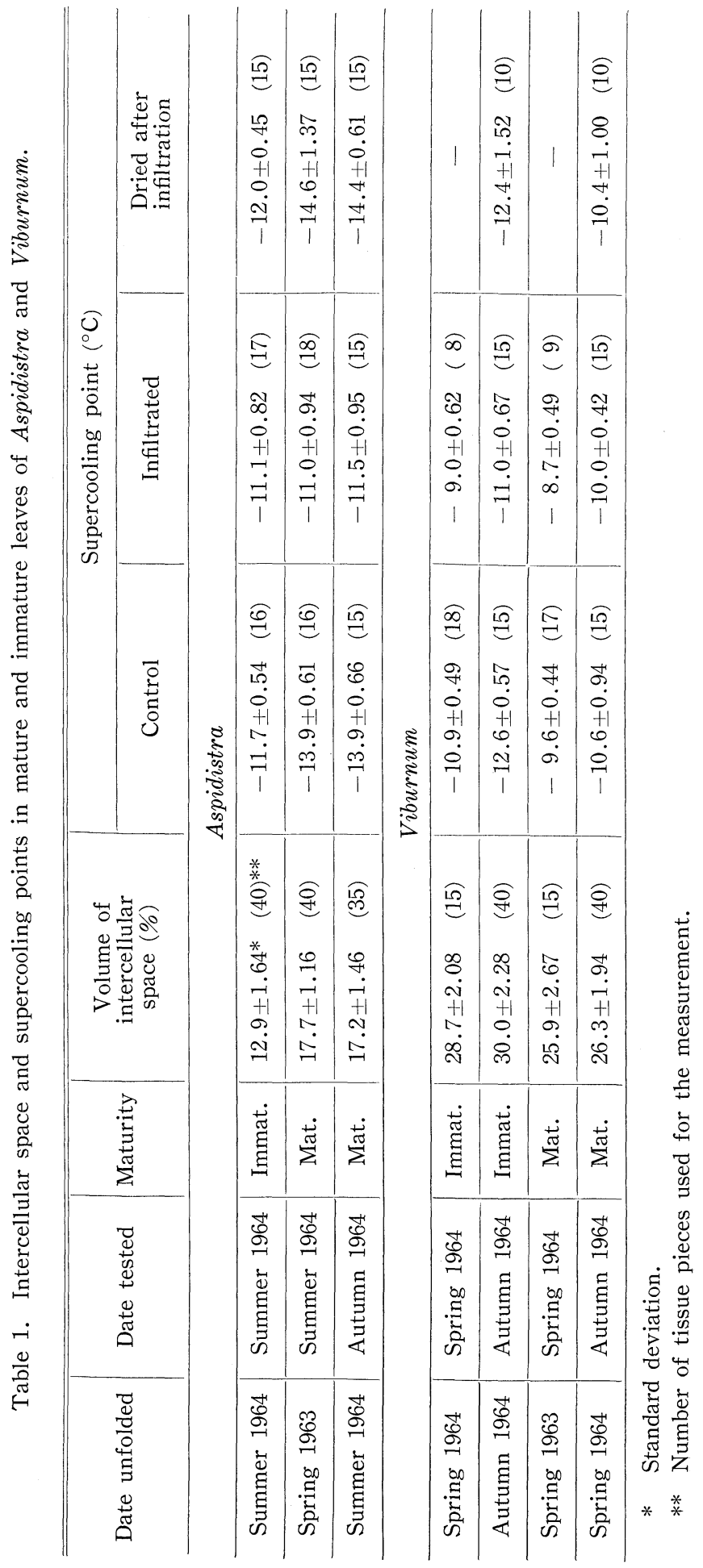


point caused by water infiltration are shown in Table 1 . The supercooling points of both mature and immature leaf tissues were elevated by this treatment. After water infiltration the difference of supercooling points between the mature and immature leaves was almost lost in Aspidistra, and in Viburnum it became less by $1.0^{\circ}$ than that of the control. The elevation of supercooling point caused by water infiltration was more marked in leaf tissues with larger volumes of intercellular space (mature Aspidistra, immature Viburnum) than in those with smaller intercellular spaces. In other words, the initiation of freezing in leaf tissues with more intercellular space was more difficult than in those with less. This suggests relevance to the fact that the intercellular space increases and supercooling point falls with the aging of leaf tissues, and vice versa.

To check the effect of water infiltration on the supercooling points of leaf tissues, the materials once infiltrated with water were dried back to the water content of the controls, and the changes of supercooling points were examined. The differences in supercooling between the mature and immature leaf tissues, which had been lost or diminished by the infiltration treatment, again appeared after drying. From these results, it seems that the difference of supercooling points between mature and immature leaves was distinctly shown only when the intercellular spaces were filled with air.

The changes of supercooling point observed in Aspidistra and Viburnum are seen to be related to the changes in volume of intercellular space accompanying maturation of the leaves. In addition, supercooling ability is larger in the tissues with more intercellular space than in those with less intercellular space. From these results, it is conceivable that supercooling ability in Aspidistra and Viburnum is related to changes in volume of intercellular space, but no causal relation is apparent.

\section{Summary}

Supercooling points of immature leaf tissues in Aspidistra showed a pronounced decrease as the leaf tissue matured. Although in Viburnum and Fatsia there were no marked age-induced changes, the supercooling points of mature leaves were higher than those in immature ones. No seasonal changes of supercooling points in mature leaves could be observed during the winter and spring in any of the three species.

Osmotic values gradually increased and water contents decreased during maturation of leaf tissues in each species. However, these changes do not affect the supercooling points to any major extent.

In Aspidstra and Viburnum, the volume of intercellular space changes as the leaf tissue grows, and is correlated with supercooling point changes, but in opposite directions in the two species. In Aspidistra, the intercellular space increased and the supercooling point fell with the aging of tissue, whereas in Viburnum the former decreased and the latter rose.

The difference in supercooling points between mature and immature leaves was diminished or almost lost when water infiltrated the intercellular spaces. In this case the elevation of supercooling points was more marked in leaf tissues with larger volumes of intercellular space than in those with smaller volumes. Thus, the difference in supercooling points between mature and immature leaf tissues in Aspidistra and Viburnum was distinctly shown only when the intercellular spaces were filled with air, and supercooling ability was larger in tissues with more intercellular space than in those with less. 
Thanks are due to Profs. E. Asahina, Institute of Low Temperature Science, Hokkaido University, and K. Aoki, Faculty of Science, Tohoku University for their valuable advice and constant interests. I am especially indebted to Dr. R. W. Salt, Research Station, Canada Department of Agriculture, Lethbridge Alberta, for his excellent criticism of the manuscript.

\section{References}

1) Chandler, W. H., Proc. Amer. Soc. Hort. Sci., 64: 552 (1954). 2) Levitt, J., The Hardiness of Plants (Academic Press, New York, 1956). 3) Lusena, C. V., Arch. Biochem. Biophys. 57: 277 (1955). $\quad$ 4) Salt, R. W., Canad. Jour. Zool. 37: 59 (1959). 5) Molisch, H., Untersuchungen über das Erfrieren der Pflanzen (Fischer, Jena, 1897). 6) D’Arsonval, M., Compt. rend. 133: 84 (1901). 7) Voigtländer, H., Beitr. Biol. Pflanz. 9: 359 (1909). 8) Kaku, S., Bot. Mag. Tokyo 77: 283 (1964). 9) Katayama, T., Proc. Crop Sci. Soc. Jap. 29: 229 (1961). 10) —, ibid 30: 150 (1962). 11) Imamura, S., and Katayama, T.C., Sci. Rep. Tohoku Univ. 4th Ser. Biol. 29: 131 (1963). 12) Iljin, W.S., Ann. Rev. Plant Physiol. 8: 257 (1957). 13) Walter, H., ibid. 6: 239 (1955). 14) Crafts, A.S., Currier, H. B., and Stocking, C. R., Water in the Physiology of Plants (Chronica Botanica, Waltham, Mass., 1949). 15) Salt, R. W., Canad. Jour. Zool. 34: 283 (1956). 16) Takenouchi, M., Bull. Sci. Fac. Agr. Kyushu Univ. 5: 254 (1932). 17) Lucus, J. W., Plant Physiol. 29: 245 (1954). 18) Iljin, W. S., Bull. assoc. russe recherches sci. Prague. Sect. sci. nat. math. 1: 1 (1934).

摘要

賀来章輔：常緑葉組織における過冷却の葉令にともなら变化と縕胞間隚量・細胞浸透価および 含水量との関係

ハラン (Aspidistra) サンゴジュ（Viburnum）およびヤツデ（Fatsia）の葉組織に抢いて，過冷却点の 葉命にともなら旼化，ならびに晚秋より翌春にか活ての成熟葉に抢けるその季節的変化を測定した。 なた， 葉組織の細胞浸透俩。含水量抢よび細胞間隙量についてもどうようの测定を捛こない，これらと過冷却と の関係を考察した。

1.八ランでは，葉組織の成熟にともない過冷却点は四らかに低下する。サンゴジュとヤッデでは，こ のような明膫な変化は認められない。しかし，両植物の成熟葉に抢汸る過冷却点は未熟葉のそれより高く， 八ランの場合とは逆の関係を示す。成熟葉の越冬期に括计る過冷却点の变化は，各植物と夕に約 $1^{\circ}$ 程度て 季節的変化は認められない.

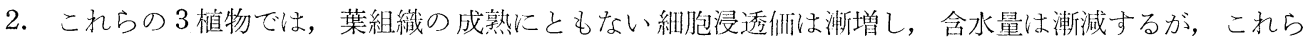
の変化は過冷却点に影響を㧍よぼすほど大きいものではない。

3. 八ラン拈よびサンゴジュの葉組織においては，細胞間吵量も葉令にともない変化するが，両植物で 逆の傾向を示し，過冷却点の変化とよく関連する。すなわち，ハランでは葉組織の成熟にともなつて細胞 間隙量は増加し，過冷却点は低下するが，サンゴジュでは逆に前者は減少し，後者は上昇する.

4. 未熟および成熟両葉組織に拈ける過冷却点の相違は，細胞間隚に水を漫潤させた場合には減殺される. そしてこのときの過冷却点の高まりの程度は，細胞間隙量の大きな組織においてょり著しい。また，この 浸潤処理をほどこした両組織を対照の含水量まで風乾すると, 過冷却点の差が対照と同程度に再現する。 すなわち，ハランおよびサンゴジュの未熟および成熟両葉組蟣に拈ける過冷却点の相違は，細胞間隙が空 気でタたされているとき顕著に現われ，細胞間隙のよく発達した組䋞ほど過冷却能力は大きい.（九州大学 教養部生物学教室) 